\title{
Fairer Handel mitder Dritten Welt
}

Pour un commerce équitable avec le Tiers Monde

\section{Andràs November}

\section{CpenEdition}

\section{Journals}

Édition électronique

URL : http://journals.openedition.org/sjep/1081

DOI : 10.4000/sjep.1081

ISSN : 1663-9677

\section{Éditeur}

Institut de hautes études internationales et du développement

\section{Édition imprimée}

Date de publication : 1 janvier 1986

Pagination : 161-176

ISSN : 1660-5926

\section{Référence électronique}

Andràs November, «Fairer Handel mitder Dritten Welt », Schweizerisches Jahrbuch für

Entwicklungspolitik [En ligne], 6 | 1986, mis en ligne le 09 mars 2013, consulté le 08 septembre 2020

URL : http://journals.openedition.org/sjep/1081 ; DOI : https://doi.org/10.4000/sjep.1081

Ce document a été généré automatiquement le 8 septembre 2020

(c) The Graduate Institute 


\section{Fairer Handel mitder Dritten Welt}

Pour un commerce équitable avec le Tiers Monde

\section{Andràs November}

\section{NOTE DE L'ÉDITEUR}

Volltext auf Französisch in Annuaire suisse de politique de développement: „Pour un commerce équitable avec le Tiers Monde”, http://aspd.revues.org/1234. 